\title{
Ethics of Undergraduate Students: A Study in Malaysian Public Universities
}

\author{
Shazaitul Azreen Rodzalan and Maisarah Mohamed Saat
}

\begin{abstract}
This paper aims to determine the ethics of undergraduate students in four aspects of moral processes; awareness, judgement, intention and behaviour. It further explores the impact of gender and academic disciplines on these four moral processes. A total of 2000 undergraduate students from six public universities in Malaysia involved in this study. Data were collected through survey consists of 14 ethical statements developed based on previous studies. Descriptive analysis (such as mean), t-test and Analysis of Variance (ANOVA) were employed for the data analysis. Overall, results reveal that student's ethical level was mixed. The results also demonstrate that engineering students have low level of ethics, as compared to social science and science students. In terms of gender differences, female students appear to have higher level of ethics than their male counterparts. The findings of this study provide some educational and theoretical implications.
\end{abstract}

Index Terms —Students' ethics, gender differences, academic disciplines.

\section{INTRODUCTION}

The increasing number of ethical scandals involving business professionals has received wide attention from the public and private sectors as well as academics. For example, the scandals of Enron and Arthur Anderson had caused chaos in the business globally in 2001. In Malaysia, a former manager of Syarikat Safire Pharmaceuticals (M) Sdn Bhd had been charged in court of money laundering for receiving RM41.3 million [1], while Ex-Sime Darby was found guilty for corruption involving over RM180, 000 [2]. All these scandals demonstrate that unethical behaviour is performed by professional groups and managers worldwide, and therefore it is important for society to be nurtured and taught with ethical values and integrity since childhood [3]. [4] supported the notion where ethical awareness should be taught in early age by providing continuous education, especially to students in higher education. Perhaps, this ongoing ethics education could produce students who embrace with values learnt in class and also develop future professional who are capable to resolve ethical dilemmas when entering the real workforce. Furthermore, university students, as future workforce and future leaders are expected to accomplish Malaysia's aim in developing an ethical community by the year 2020 as emphasized in Vision 2020 challenges (Vision 2020).

The objective of this study is twofold; first, this study

Manuscript received December 14, 2014; revised April 22, 2015.

The authors are with the Faculty of Management, University of Technology Malaysia, 81310, Skudai, Johor, Malaysia (e-mail: sazreen3@live.utm.my, maisarahsaat@utm.my). determines the ethics among undergraduate students in Malaysian public universities with regards to four aspect of moral processes; awareness, judgement, intention and behaviour. Secondly, this study also identifies differences between academic disciplines and gender on their level of ethics. This paper will focus on social science, science and engineering programs, as three programs are different in nature. It is anticipated that the study provide interesting findings in their level of ethics. The community is the primary interest in this study in that the findings will indicate whether the university will nurture students with values and thus develop their high level of ethicality. The community is expecting future professionals to behave ethically in conducting their work. Furthermore, the findings of this study provide significance to students, professional bodies and higher learning institution, mainly to public universities in Malaysia. By investigating the ethics of these future professional groups, higher learning institutions can identify to what extent students benefits from ethics education learnt in classroom. Meanwhile, the findings also serve as an alert to professional bodies on their responsibility of ethical modelling in order to improve future workforce ethics. Moreover, the findings of this study make an important contribution to the ethics literature and learning outcome, particularly in Malaysia. It provides insight on how students will deal when given with ethical situations. It also indicates student's ethicality in a country and serves an indicator to what extent they have prepared in improving ethicality of the entire community.

This paper is structured as follows: The next section will review a model of moral processes and followed by a review on past literature on the impact of gender and academic disciplines towards ethics. The subsequent section proposes the method use in conducting the study, while the next section presents the results of this study. In the last section, this study will make conclusions by proposing some limitation and recommendations for future research.

\section{LITERATURE REVIEW}

\section{A. Rest's Model of Four Processes}

Ref. [5] shared similar view with Kohlberg where individual's moral judgement develops through a sequence of stages. Extending Kohlberg's view, [6] asserted that individuals achieve better judgement as they are being influenced by life experience, education, religion and social environment. Since Kohlberg's discussion only focusing on Moral judgement component [5], [7] proposes that in behaving morally in a particular situation, an individual performs four processes; moral awareness, moral judgement, 
moral intention and moral behaviour.

Moral awareness is a process where an individual has the ability to recognize and interpret that a situation contains a moral issue. It requires the individual to aware of who is involved, identify how one's action or inaction will harm and/or benefit others and able to think cause-effect relationships of the ethical situation [7]. The individual must understand the existence of ethical issue so that he or she can act ethically and avoid to unethical action [8], as he or she realizes the consequences of a particular situation can "affect the needs, interest, welfare and expectation of others" [7]. Although individual is sensitive or aware to ethical situation, it does not indicate the outcome of the decision process. Early exposure towards ethical situation is necessary; mainly to university students such as provide training so that they can acquire some experience on how to handle real ethical situations in future [9]. The exposures to ethical situation may be necessary, but not sufficient to change one's ethical behaviour [10].

Once an individual recognizes a moral issue, judging which action is morally right and fair begins the next process of moral development. In other words, moral judgement refers to one's ability to decide a particular action in a moral sense after considering course of action and possible consequences [11]. According to Rest, this process involves individual's cognitive development by "understanding of the purpose, function and nature of social cooperation" [7]. Some social experiences have a long term impact on one's judgement and featured by general concept of justice, which is the underlying concept of Kohlberg's moral development stages [12]. Thus, justice consideration may assist individual to justify a moral course of action. Kohlberg's claimed that one's develop moral judgement with age and progress through six stages. Based on Kohlberg's theory, [7] asserts that from simple levels of cooperation (lower stage), individual becomes sensitive and develop to "more complicated schemes of cooperation involving long-term, society networks and institutionalized role systems...called stages of moral reasoning (moral judgement)". Rest also argues that factors such social or cultural norms, political ideology and religious belief may undermine justice concept in making ethical judgement.

The subsequent step in the process is prioritizing moral concerns over competing issues. It also refers to moral intention or moral motivation of the individual. [7] described moral motivation as the degree of commitment in taking a particular course of action, choosing one moral value over another, and taking personal responsibility for the outcomes of their actions. An individual triggers to act morally either in conscious or unconscious, as well as based on intuitive, effortful, intentional and controllable moral judgment [13]-[15]. This process involves interconnection between cognition and affection, where visualizing the desire goals is part of cognitive, whereas affective response occur when having determination in achieving the goals.

After deciding a desired outcome, the next step in the process is transforming the intention into actual behaviour. It is said that one performs what one believes to be a moral action [11]. According to [7], an individual will persist with task, having courage, overcoming fatigue, avoiding temptation and implementing subroutines that serve a moral goal. Ego strength or self-regulation serves as an important component in this stage. The individual with high ego strength are inclined to have consistent moral cognition or act morally as they stand with their own principles [16]. Hence, it is consistent with the argument that people with high ego strength are less likely to cheat [17]. Since this moral behaviour will determine the outcome of ethical situation, actions may be taken in order to nurture the youngest with high ethical values, by increasing moral awareness, moral judgement and moral intention through ethics education.

\section{B. Gender Differences and Ethics}

Numerous past studies revealed that gender does influence one's level of ethics [11], [18]-[25]. Most of these studies reported that female students are more ethical than male students. For example, a recent study by [18] shows that female students possessed with high values in terms of honesty and religiosity, compared to their male counterparts. In other study, a total of 725 business students across five campuses were surveyed in regards to examine their ethical behaviours. They were asked to rank a list of 17 ethical behaviours and the findings showed that female students behave ethically than male students, as they do not to take organization items for personal use and do not exchange the preferential treatment by accepting gifts or favours. These consistent with a study by [20] as they found female students were less acceptable to cheat as compared to male students. It is probably due to negative consequences of cheating such as suspension of study. In addition, [11] studied on perception of ethical awareness among 1274 students by asking them to rate their acceptance on 15 ethical situations. The results indicated that female students have higher ethical awareness than male students in ten ethical situations involving gender discrimination, stealing information, cronyism, product design flaw and keep incorrect change.

Unlike previous findings, a study by [26] found that men and women have similar ethical perceptions on business ethics. Besides, [25] also reported equal findings where there is no difference between genders on level of ethics. In addition, ethical belief between male and female students is similar, which indicate that a study by [24] was supported the prior findings. Based on the mixed findings, it demonstrates that one's ethical perception may vary when given with different ethical situations.

\section{Academic Discipline and Ethics}

The distinctions across academic discipline, due to nature of work motivate the present study to examine whether academic discipline gives impact to students' ethical perceptions. Based on findings of past studies, it shows that academic discipline has influenced on ethical perceptions [11], [22], [25], [27]. For example, [24] surveyed 345 fourth year undergraduate students from six different majors in regards to explore the influence of students' characteristics on their level of ethics. The findings reveal that Information Systems students have significantly higher ethics score than those in Finance, Marketing and Non-Business majors. In the meantime, [22] also reported consistent findings where accounting students were less likely to commit with unethical practices, involving personal use, passing blame, bribery, 
falsification, padding expenses and deception compared to students in management, psychology and others majors. In addition, [11] compared ethical awareness of engineering and non-engineering majors in a university. They found that engineering students demonstrate a slightly lower level of ethical awareness towards business and workplace ethics, rather than non-engineering students. In terms of gender differences, female engineering students were reported to have higher ethical awareness compared to male engineering students. However, this is contrast to findings by [27] as engineering students perceive themselves more sensitive towards ethical issues than their colleagues in other majors. In other words, engineering students are more ethical than others.

\section{MethodolOGY}

In achieving the objectives of this study, the researcher have self administered a survey on 2800 final year students from six public universities in Malaysia. Of the 2800 students, a total of 2000 students were found to complete the questionnaire indicating a response rate of $71.4 \%$. These students were enrolled in three different academic disciplines; namely Social Science, Science and Engineering. In Social Science discipline, the participation was from students in five programs; consist of accounting, human resource management, management technology, marketing and psychology. Besides, students from science discipline enrolled in four programs including biology, chemistry, physics and mathematical science programs. Meanwhile, engineering discipline involves students in three programs of civil, mechanical and electrical. The questionnaire was in English and Malay languages. Essentially, the questionnaire consists of two parts. In Part A, the respondents were asked to complete demographic information such as gender, race, age and academic discipline. Meanwhile, Part B of the questionnaire has items measuring ethical behaviour and ethical practice, where respondents were required to indicate their agreement using seven point scale ranging from "strongly disagree" (1) to "strongly agree" (7). All statements used in obtaining level of ethical behaviour and ethical practice data were adapted from various sources [28]-[32]. In order to achieve the objectives, this study analyses data using descriptive analysis (such as mean), t-test and ANOVA. The descriptive analysis was used to determine the frequency of demographic profile and mean score for each ethics statements, while the differences between gender and academic disciplines on students' ethics was identified using t-test and ANOVA.

\section{RESULTS}

\section{A. Respondents' Profile}

The following analysis was to report students' demographic information, related to gender, age, races and academic discipline (refer Table I). Out of 2000 respondents, 682 were male students $(34.1 \%)$ and 1318 were female students $(65.9 \%)$. In regards to age, majority of respondents $(87.7 \%)$ were between 19 to 24 years, while the remaining
$12.4 \%$ of the respondents were between 25 years and above. Furthermore, Malay respondents $(69.8 \%)$ dominate the sample, followed by Chinese respondents $(24.1 \%)$, while the rest are Indians $(2.5 \%)$ and others races respondents $(3.6 \%)$. Meanwhile, the number of social science respondents was the highest, which is $39.3 \%$ as compared to engineering (32.4\%) and science $(28.4 \%)$ respondents.

TABLE I: DISTRIBUTION OF STUDENTS' DEMOGRAPHIC

\begin{tabular}{lcc}
\hline \hline Students' Demographic & Frequency (N) & Percentage (\%) \\
\hline Gender & 682 & 34.1 \\
$\quad$ Male & 1318 & 65.9 \\
Female & & \\
Age & 1753 & 87.7 \\
$19-23$ & 247 & 12.4 \\
24 and above & & \\
Race & 1396 & 69.8 \\
$\quad$ Malay & 482 & 24.1 \\
Chinese & 49 & 2.5 \\
Indian & 72 & 3.6 \\
$\quad$ Others & & \\
Academic Discipline (AD) & 785 & 39.3 \\
Social Science (SS) & 568 & 28.4 \\
$\quad$ Science (S) & 647 & 32.4 \\
$\quad$ Engineering (E) & & \\
\hline \hline
\end{tabular}

\section{B. Ethics of Students}

In achieving the first objective of this study, the mean score for each ethics statement were computed. The first six statements in Table II refer to negative statements of ethics, while the rest are positive statements. For the negative statements, high level of ethics is considered if student's score mean of below 4.00, while the mean score of 4.00 and above refer to low level of ethics. For the first three negative statements, results show that students were more inclined not to behave unethically (such as plagiarizing, stealing) with the mean score below than 4.00. In fact, they would refuse to commit unethical action although being asked by their lecturers. Thus, the lower score of mean demonstrates a tendency not to agree indicating a high level of ethics. However, students seemed to have low level of ethics when the situation is beyond their control and involve their friends. Besides, they also agreed that using office equipment (such copy machine, paper) for personal use is considered as not unethical behaviour, which imply a low awareness of ethics. Based on the mixed results, it shows that students would behave ethically or unethically according to the situation they deal with. In fact, the inclination to accept using office supplies as not an unethical behaviour may be results from their observation.

For positive statements, students who scored mean of 4.00 and above were considered to have high ethical level. In this study, students' scored mean above 4.00 for all positive statements except for the last statement related to reward. The results indicated that students possessed with high level of ethics as they believed honesty is more important than getting good grades. Furthermore, the action of taking responsibility on their own action demonstrates that students have high level of ethical behaviour. Other than that, students agreed that regulations and code of ethics is one of the factors that lead them to behave ethically. Even though they personally dealt with ethical dilemmas, the ambiguous and unpredictable 
ethical situation brings them to rely on others (lecturers) by taking all opinions and considerations before making a decision. In other words, these students can be considered to have high moral judgement when facing ethical dilemmas. The result in Table II also revealed that faculty (lecturers and administrator) do not provide reward when students behave ethically as the mean score is the lowest (3.96). It is undeniable that reward could motivate students to behave ethically, but the faculty may believe that it only works in the short period of time.

TABLE II: COMPUTED MEANS FOR STATEMENTS OF ETHICS

\begin{tabular}{|c|c|c|}
\hline Statements & Mean & SD \\
\hline $\begin{array}{l}1 \text { I behave unethically when asked to do so by my } \\
\text { lecturers even though it contradicted my ethical } \\
\text { principle. }\end{array}$ & 3.41 & 1.65 \\
\hline $\begin{array}{l}2 \text { When my lecturers asked me to do something } \\
\text { unethical, I was committed to show my obedience. }\end{array}$ & 3.48 & 1.78 \\
\hline $\begin{array}{l}3 \text { I behave unethically (ie. plagiarized, stealing) } \\
\text { because of pressures (ie. time and cost constraint). }\end{array}$ & 3.55 & 1.78 \\
\hline $\begin{array}{l}4 \text { I prefer not to report friends' unethical behaviour to } \\
\text { lecturers. }\end{array}$ & 4.07 & 1.79 \\
\hline $\begin{array}{l}5 \text { I commit unethical action when it is beyond my } \\
\text { control (ie. I plagiarize because the academic system } \\
\text { emphasis on excellent results). }\end{array}$ & 4.31 & 1.56 \\
\hline $\begin{array}{l}6 \text { Using a copy machine, paper and other supplies for } \\
\text { personal use is not unethical behaviour. }\end{array}$ & 4.44 & 1.80 \\
\hline $\begin{array}{l}7 \text { I hold to my principle that honesty is important than } \\
\text { getting good grade. }\end{array}$ & 5.58 & 1.21 \\
\hline $\begin{array}{l}8 \text { I take full responsibility if I do any unethical action } \\
\text { (ie. I confess if lecturers found me plagiarize some } \\
\text { works). }\end{array}$ & 5.35 & 1.20 \\
\hline $\begin{array}{l}9 \text { I behave ethically in adherence to regulation and code } \\
\text { of ethics outlined by university. }\end{array}$ & 5.06 & 1.25 \\
\hline $\begin{array}{l}10 \text { I will take all opinions/considerations from others if I } \\
\text { need to make a decision on ethical dilemma. }\end{array}$ & 5.05 & 1.24 \\
\hline $\begin{array}{l}11 \text { During my study in university, I referred to others to } \\
\text { resolve ethical dilemmas. }\end{array}$ & 5.03 & 1.21 \\
\hline $\begin{array}{l}12 \text { I personally dealt with ethical dilemmas during } \\
\text { studying in university. }\end{array}$ & 4.72 & 1.47 \\
\hline $\begin{array}{l}13 \text { I have been confronted with ethical dilemmas during } \\
\text { studying in university. }\end{array}$ & 4.21 & 1.60 \\
\hline $\begin{array}{l}14 \text { The faculty (ie lecturers, administrator) will reward } \\
\text { me when I do something ethical. }\end{array}$ & 3.96 & 1.52 \\
\hline
\end{tabular}

\section{Differences on the Level of Ethics between Genders Based on Academic Discipline}

Further analysis is conducted to see the difference of ethics level between gender (refer Table III(a) and Table III(b)). Table III(a) shows that female students from all programs display higher ethical behaviour than male students (highly significant at $p<0.01$ ) as they refused to behave unethically although being ordered by lecturers and decline to plagiarize and steal. In reporting a friend's unethical behaviour, there is a significant difference between male and female students who enrolled in social science program $(t=3.865, p<0.01)$. The difference was further explored by measuring mean scores for both genders (see Table III(a)). It appears that female students of social science prefer to report their friend's unethical behaviour, rather than male students. However, the other two programs of study did not report any significant different in gender.

Based on Table III(b), there were also significant differences between gender and ethical perception in terms of honesty principle among science students $(t=-3.955, p<0.01)$ while engineering students differ significantly in adherence to regulations and code of ethics $(t=3.865, p<0.01)$. Only social science students show the difference in perception between genders regarding statement of personally dealt with ethical dilemmas. In addition, male students from both social science $(t=-2.644, \quad p<0.01)$ and engineering $(t=2.175, \quad p<0.05)$ perceived they did not confronted with ethical dilemmas during studying in university, compared to female students. In the last statements on reward, female students from social science were more inclined to agree that the faculty will reward ethical behaviour. In summary, the results of mean differences between genders suggest that female students have higher level of ethics as compared to male students. This is consistent with previous studies by [11], [23].

TABLE III(A): COMPARE MEANS BETWEEN GENDER AND ETHICS STATEMENTS ACCORDING TO ACADEMIC DISCIPLINES

\begin{tabular}{|c|c|c|c|c|c|c|}
\hline No. & Statements & AD & Male & Female & $t$ & Sig. \\
\hline \multirow{3}{*}{\multicolumn{2}{|c|}{$\begin{array}{l}1 \text { I behave unethically } \\
\text { when asked to do so by } \\
\text { my lecturers even though } \\
\text { it contradicted my } \\
\text { ethical principle. }\end{array}$}} & $\mathrm{SS}$ & 3.56 & 3.18 & 2.826 & $.005 * *$ \\
\hline & & $\mathrm{S}$ & 3.65 & 3.15 & 3.195 & $.001 * *$ \\
\hline & & $\mathrm{E}$ & 3.94 & 3.46 & 3.738 & $.000 * *$ \\
\hline \multirow[t]{3}{*}{2} & \multirow{3}{*}{$\begin{array}{l}\text { When my lecturers asked } \\
\text { me to do something } \\
\text { unethical, I was } \\
\text { committed to show my } \\
\text { obedience. }\end{array}$} & $\mathrm{SS}$ & 3.83 & 3.25 & 3.954 & $.000 * *$ \\
\hline & & S & 3.70 & 3.20 & 3.258 & $.001 * *$ \\
\hline & & $\mathrm{E}$ & 3.88 & 3.51 & 2.637 & $.009 * *$ \\
\hline \multirow[t]{3}{*}{3} & \multirow{3}{*}{$\begin{array}{l}\text { I behave unethically (ie. } \\
\text { plagiarized, stealing) } \\
\text { because of pressures (ie. } \\
\text { time and cost } \\
\text { constraint). }\end{array}$} & $\mathrm{SS}$ & 3.74 & 3.25 & 3.388 & $.001 * *$ \\
\hline & & S & 3.73 & 3.27 & 2.700 & $.007 * *$ \\
\hline & & $\mathrm{E}$ & 4.22 & 3.56 & 4.894 & $.000 * *$ \\
\hline \multirow{3}{*}{\multicolumn{2}{|c|}{$\begin{array}{l}4 \text { I prefer not to report } \\
\text { friends' unethical } \\
\text { behaviour to lecturers. }\end{array}$}} & $\mathrm{SS}$ & 4.07 & 3.57 & 3.865 & $.000 * *$ \\
\hline & & S & 4.36 & 4.14 & 1.520 & .129 \\
\hline & & E & 4.47 & 4.33 & 1.373 & .170 \\
\hline \multirow[t]{3}{*}{5} & \multirow{3}{*}{$\begin{array}{l}\text { I commit unethical } \\
\text { action when it is beyond } \\
\text { my control (ie. I } \\
\text { plagiarize because the } \\
\text { academic system } \\
\text { emphasis on excellent } \\
\text { results). }\end{array}$} & $\mathrm{SS}$ & 4.26 & 4.21 & .388 & .698 \\
\hline & & S & 4.33 & 4.19 & .875 & .382 \\
\hline & & $\mathrm{E}$ & 4.51 & 4.48 & .211 & .833 \\
\hline \multirow[t]{3}{*}{6} & \multirow{3}{*}{$\begin{array}{l}\text { Using a copy machine, } \\
\text { paper and other supplies } \\
\text { for personal use is not } \\
\text { unethical behaviour. }\end{array}$} & $\mathrm{SS}$ & 4.32 & 4.25 & .440 & .660 \\
\hline & & S & 4.42 & 4.46 & -.260 & .795 \\
\hline & & E & 4.68 & 4.64 & .313 & .755 \\
\hline
\end{tabular}

Note: AD: Academic discipline; SS: Social Science; S: Science; E: Engineering

** Significant at the 0.01 level (2-tailed); * Significant at the 0.05 level (2-tailed)

\section{Differences on the Level of Ethics between Academic Discipline}

Table IV(a) and Table IV(b) present the ANOVA results which show that there are differences in the level of ethics based on academic discipline. The differences were highly significant in all negative and positive statements as $p<0.01$. However, there is no significant difference in positive statements related to refer others to solve ethical dilemmas (Statement 11), personally deal with ethical dilemmas (Statement 12) and receive reward if act ethically (Statement 14). To further examine the differences in these statements, a Bonferroni post hoc test was run indicated that engineering students were more unethical than social science and science students all negative statements. The engineering students would act unethically when they encountered with the situations such as being asked by lecturers, having pressures and the situations is beyond their control. In the statement of 
using office supplies for personal use, there is a significant different between social science and engineering students $(p=.000)$. Interestingly, in the statement of prefer not to report friends' unethical behaviour to lecturers revealed that there were significant differences between social science students and both engineering and science students (both are $p=.000$ ), and same goes to science and engineering students $(p=.043)$. Most probably, students try to maintain good relationship with their friends, so that they choose not to report to the lecturers.

TABLE III(B): COMPARE MEANS BETWEEN GENDER AND ETHICS STATEMENTS ACCORDING TO ACADEMIC DisCIPLINES

\begin{tabular}{|c|c|c|c|c|c|c|}
\hline No. & Statements & AD & Male & Female & $t$ & Sig. \\
\hline \multirow[t]{3}{*}{7} & \multirow{3}{*}{$\begin{array}{l}\text { I hold to my principle that honesty is important } \\
\text { than getting good grade. }\end{array}$} & $\mathrm{SS}$ & 5.69 & 5.64 & .510 & .610 \\
\hline & & $\mathrm{S}$ & 5.26 & 5.72 & -3.955 & $.000 * *$ \\
\hline & & $\mathrm{E}$ & 5.39 & 5.54 & -1.555 & .121 \\
\hline \multirow[t]{3}{*}{8} & \multirow{3}{*}{$\begin{array}{l}\text { I take full responsibility if I do any unethical } \\
\text { action (ie. I confess if lecturers found me } \\
\text { plagiarize some works). }\end{array}$} & SS & 5.51 & 5.42 & .889 & .374 \\
\hline & & $\mathrm{S}$ & 5.30 & 5.38 & -.676 & .499 \\
\hline & & $\mathrm{E}$ & 5.22 & 5.25 & -2.50 & .803 \\
\hline \multirow[t]{3}{*}{9} & \multirow{3}{*}{$\begin{array}{l}\text { I behave ethically in adherence to regulation and } \\
\text { code of ethics outlined by university. }\end{array}$} & $\mathrm{SS}$ & 5.24 & 5.19 & .431 & .667 \\
\hline & & $\mathrm{S}$ & 5.00 & 5.09 & -.816 & .415 \\
\hline & & $\mathrm{E}$ & 4.77 & 5.02 & -2.602 & $.009 * *$ \\
\hline \multirow[t]{3}{*}{10} & \multirow{3}{*}{$\begin{array}{l}\text { I will take all opinions/considerations from others } \\
\text { if I need to make a decision on ethical dilemma. }\end{array}$} & SS & 5.26 & 5.12 & 1.367 & .172 \\
\hline & & $\mathrm{S}$ & 5.03 & 5.11 & -.701 & .484 \\
\hline & & E & 4.88 & 4.88 & -0.43 & .966 \\
\hline \multirow[t]{3}{*}{11} & \multirow{3}{*}{$\begin{array}{l}\text { During my study in university, I referred to others } \\
\text { to resolve ethical dilemmas. }\end{array}$} & SS & 5.20 & 5.06 & 1.356 & .176 \\
\hline & & $\mathrm{S}$ & 4.94 & 5.02 & -.650 & .516 \\
\hline & & $\mathrm{E}$ & 4.92 & 5.07 & -1.690 & .092 \\
\hline \multirow[t]{3}{*}{12} & \multirow{3}{*}{$\begin{array}{l}\text { I personally dealt with ethical dilemmas during } \\
\text { studying in university. }\end{array}$} & $\mathrm{SS}$ & 5.04 & 4.66 & 2.994 & $.003 * *$ \\
\hline & & $\mathrm{S}$ & 4.66 & 4.62 & .265 & .791 \\
\hline & & $\mathrm{E}$ & 4.81 & 4.71 & .877 & .381 \\
\hline \multirow[t]{3}{*}{13} & \multirow{3}{*}{$\begin{array}{l}\text { I have been confronted with ethical dilemmas } \\
\text { during studying in university. }\end{array}$} & $\mathrm{SS}$ & 4.55 & 4.19 & 2.644 & $.008 * *$ \\
\hline & & $\mathrm{S}$ & 4.25 & 3.97 & 1.795 & .073 \\
\hline & & $\mathrm{E}$ & 4.39 & 4.13 & 2.175 & $.030 *$ \\
\hline \multirow[t]{3}{*}{14} & \multirow{3}{*}{$\begin{array}{l}\text { The faculty (ie lecturers, administrator) will } \\
\text { reward me when I do something ethical. }\end{array}$} & SS & 4.27 & 3.95 & 2.317 & $.021 *$ \\
\hline & & $\mathrm{S}$ & 3.78 & 3.93 & -1.072 & .284 \\
\hline & & $\mathrm{E}$ & 4.03 & 3.84 & 1.612 & .107 \\
\hline
\end{tabular}

** Significant at the 0.01 level (2-tailed); * Significant at the 0.05 level (2-tailed)

TABLE IV(A): COMPARE MEANS BETWEEn GENDER AND ETHICS STATEMENTS ACCORding to ACADEMIC DisCIPLINES

\begin{tabular}{|c|c|c|c|c|c|c|c|c|c|c|}
\hline \multirow[t]{2}{*}{ No. } & \multirow[t]{2}{*}{ Statements } & \multicolumn{3}{|c|}{ Frequency Distribution } & \multicolumn{2}{|c|}{ ANOVA } & \multicolumn{4}{|c|}{ Bonferroni post hoc tests } \\
\hline & & 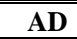 & Mean & SD & $\bar{F}$ & Sig. & 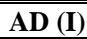 & $\mathbf{A D}(\mathbf{J})$ & Mean Difference (I-J) & Sig. \\
\hline & I behave unethically when asked to do so by my & SS & 3.27 & 1.66 & & & SS & $\mathrm{S}$ & -0.01 & 1.000 \\
\hline & lecturers even though it contradicted my ethical & $\mathrm{S}$ & 3.28 & 1.62 & 15.34 & $.000 * *$ & SS & $\mathrm{E}$ & -0.44 & $.000 * *$ \\
\hline \multirow[t]{3}{*}{2} & When my lecturers asked me to do something & SS & 3.40 & 1.81 & & & SS & $\mathrm{S}$ & 0.07 & 1.000 \\
\hline & unethical, I was committed to show my obedience. & S & 3.33 & 1.72 & 8.12 & $.000 * *$ & SS & $\mathrm{E}$ & -0.30 & $.004 * *$ \\
\hline & & $\mathrm{E}$ & 3.70 & 1.76 & & & S & $\mathrm{E}$ & -0.37 & $.001 * *$ \\
\hline \multirow{2}{*}{3} & because of pressures (ie. time and cost constraint). & S & 3.39 & 1.77 & 19.96 & $.000 * *$ & SS & $\mathrm{E}$ & -0.54 & $.000 * *$ \\
\hline & & $\mathrm{E}$ & 3.91 & 1.74 & & & S & $\mathrm{E}$ & -0.52 & $.000 * *$ \\
\hline & I prefer not to report friends' unethical behaviour to & SS & 3.70 & 1.59 & & & SS & S & -0.50 & $.000 * *$ \\
\hline & lecturers. & S & 4.20 & 1.50 & 43.41 & $.000 * *$ & SS & $\mathrm{E}$ & -0.71 & $.000 * *$ \\
\hline & & $\mathrm{E}$ & 4.41 & 1.33 & & & $S$ & $\mathrm{E}$ & -0.21 & $.043 *$ \\
\hline \multirow[t]{2}{*}{5} & I commit unethical action when it is beyond my & SS & 4.22 & 1.62 & & & SS & S & -0.01 & 1.000 \\
\hline & system emphasis on excellent resu & $\mathrm{E}$ & 4.50 & 1.42 & & & S & $\mathrm{E}$ & -0.27 & $.007 * *$ \\
\hline \multirow[t]{3}{*}{6} & Using a copy machine, paper and other supplies for & SS & 4.26 & 1.91 & & & SS & S & -0.19 & .178 \\
\hline & personal use is not unethical behaviour. & S & 4.45 & 1.82 & .854 & $.000 * *$ & SS & E & -0.40 & $.000 * *$ \\
\hline & & $\mathrm{E}$ & 4.66 & 1.59 & & & S & $\mathrm{E}$ & -0.21 & .135 \\
\hline
\end{tabular}

** Significant at the 0.01 level (2-tailed); * Significant at the 0.05 level (2-tailed)

For the remaining positive statements in Table IV(b), the Bonferroni post hoc test results shows that social science students inclined to behave ethically than engineering students in the statements of holding principle of honesty is more important than getting good grade $(p=.008)$ and taking full responsibility for unethical action $(p=.004)$. Meanwhile, social science $(p=.000)$ and science $(p=.035)$ students adhered to regulations and code of ethics, as compared to engineering students as there is a significant differences between these two groups. Similarly, social science $(p=.000)$ and science $(p=.009)$ students willing to take all opinions or consideration from others if they need to make a decision on ethical dilemma. In contrast, science students revealed that they are less confronted with ethical dilemma, where there is a 
significant differences with both social science $(p=.018)$ and engineering students $(p=.043)$. There were no significant differences between programs of study in the remaining three statements. In overall, the results suggest that engineering students were not possessed with high level of ethics, as compared to social science and science students. It is probably due to the nature of the engineering program itself that known as one of the critical and tough program which urge the students to compromise with their own ethics principle in order to achieve the goals.

TABLE IV(B): COMPARE MEANS BETWEEN GENDER AND ETHICS STATEMENTS ACCORDING TO ACADEMIC DISCIPLINES

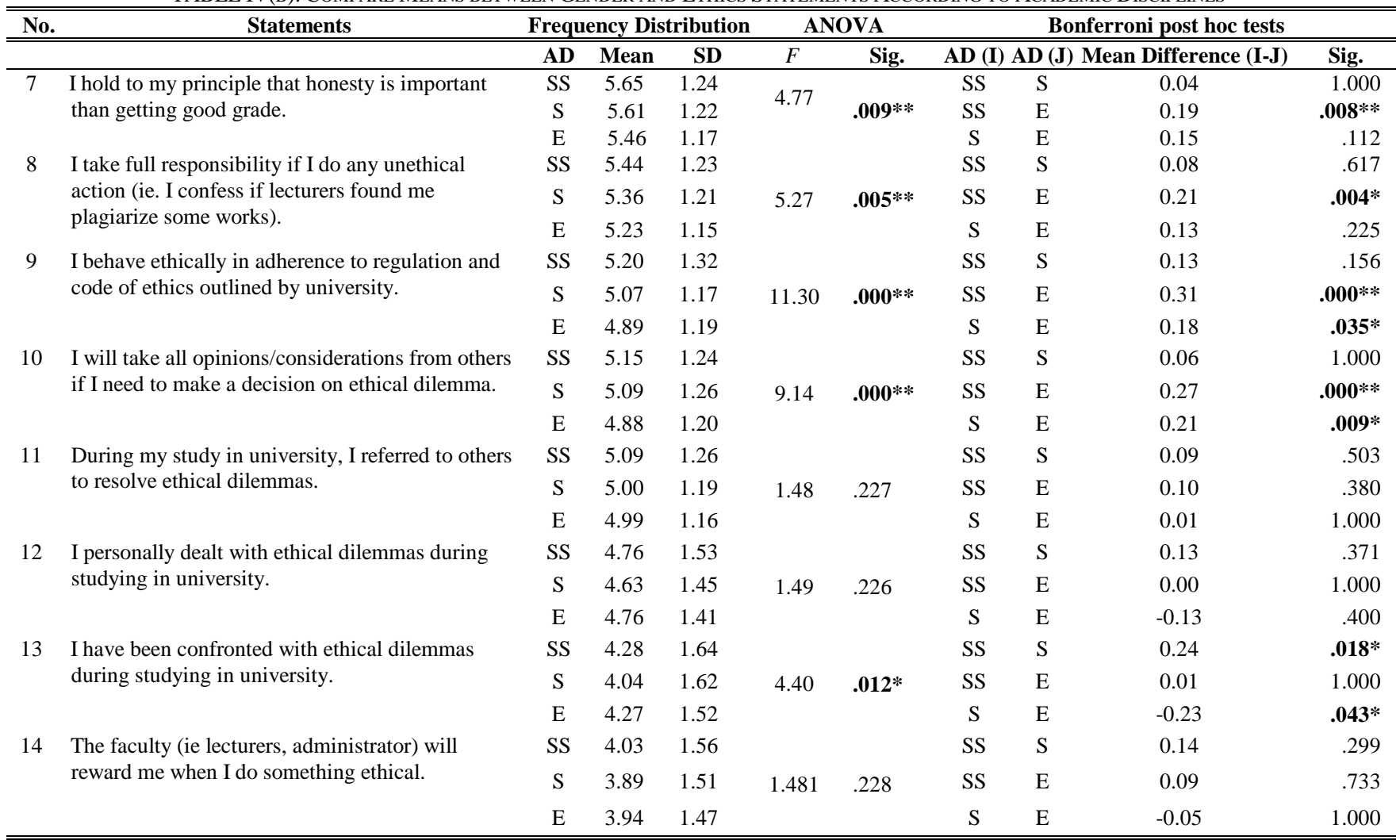

** Significant at the 0.01 level (2-tailed); $*$ Significant at the 0.05 level (2-tailed)

\section{DISCUSSION AND CONCLUSION}

In general, the study revealed that students have high level of ethics, but it differs when the situation is beyond their control and involve their friends. In other words, the inclination towards unethical action may due to the nature of ethical situation itself. For example, students appeared to have high tolerance in using office supplies as they may consider it as not unethical behaviour. It shows that students are less awareness on ethical issues. Findings of the study revealed consistent findings with past studies indicating that female have high level of ethics as they were more compassionate, caring and more appreciate relationship [26], [33] while male were more aggressive and competitive when come to situation where they need to compete and intend to behave unethically. In contrast to the argument made by past studies, the present study found that female students tend to report friend's unethical behaviour which would affect their relationship. Most probably, they hold with high ethical principle for not conspiring with those who commit unethical action. Finding on the differences of gender and academic discipline towards ethics show interesting result. It appears that female students have high level of ethics, which consistent with past studies (Saat et al., 2012). Other than that, the study also revealed that the level of ethics could be different in terms of academic discipline. Overall, the ethical level of engineering students were slightly lower than the other two disciplines (refer to social science and science) with the respect of significant differences in all six negative statements and five out of eight positive statements. Engineering students are found to have lower level of ethics related to plagiarizing and whistleblowing.

Based on the findings, it is important for university to prepare students with ethical knowledge, skills and values in order to react with ethical dilemmas and capable to make ethical decision once enter in real world of work. Therefore, this study recommends that university should promote the ethics values through training, seminar and colloquium. For example, students are send for industrial training up to six months either in public or private organizations in order to expose them with real ethical situations outside the campus. Besides, this study proposes that students may be more ethical if the curriculum integrates ethics education in all relevant course as well as introducing the stand alone course. Nevertheless, the university should ensure these courses are effective and the learning outcomes are achieved. In the meantime, the faculty administrator and academicians should serves as a role model which it can significantly influence one's ethical judgment [34].

\section{LIMITATIONS AND FUTURE RESEARCH}

This study has its limitations, where they should be acknowledged by proposing recommendations for future 
research. Firstly, the sample of student in this study has not being exposed with working experience, or known as industrial training. It would be useful for future research to conduct a longitudinal study that follow students into their industrial training in order to measure their moral development, in order to determine benefits gained from real working environment. Secondly the study only focuses on students from public university; hence it is very meaningful if private university being considered for future research due to the distinction on both institutions [35]. The third limitation in this study is regarding the method used. This limitation might give a different view and result if compared to other research that using mixed-mode method (both survey and interview).

\section{REFERENCES}

[1] Bernama. (March 21, 2012). Dr Hamimah gets 38 years jail, RM6.39mil fine for money laundering. The Star Online. [Online] Available: http://www.thestar.com.my

[2] Bernama. (April 12, 2012). Ex-Sime Darby senior GM gets 27 years for corruption. The Star Online. [Online]. Available: http://www.thestar.com.my

[3] C. O'Leary, "An empirical analysis of the positive impact of ethics teaching on accounting students," Accounting Education, vol. 18, no. 4-5, pp. 505-520, 2008.

[4] L. Kohlberg, Essays on Moral Development. The Philosophy of Moral Development. Moral Stages and the Idea of Justice, New York, USA: Harper \& Row, 1981.

[5] J. Rest, D. Narvaez, M. J. Bebeau, and S. J Thoma, Postconventional Moral Thinking a Neo Kohlbergian Approach, Lawrence Erlbaum Associates, Inc., 1999.

[6] J. Rest, D. Narvaez, M. J. Bebeau, and S. J Thoma, "Alchemy and beyond: Indexing the defining issues test," Journal of Educational Psychology, vol. 89, no. 3, pp. 498-50, 1997.

[7] J. R. Rest, "Research on moral development: Implications for training counseling psychologists," The Counseling Psychologist, vol. 12, no. 3, pp. 19-29, 1984

[8] M. B. Armstrong, "Ethics and professionalism in accounting education: A sample course," Journal of Accounting Education, vol. 11, no. 1, pp. 77-92, 1993.

[9] L. K. Treviño, G. R. Weaver, and S. J. Reynolds, "Behavioral ethics in organizations: A review," Journal of Management, vol. 32, no. 6, pp. 951-990, 2006.

[10] B. Jamshidinavid and F. Kamari, "Ethics in management accounting: Moving toward ethical motivation," Research Journal of Finance and Accounting, vol. 3, no. 6, pp. 90-96, 2012.

[11] M. M. Saat, H. A. Rahman, and A, "Rajab, The impact of industrial training on ethical awareness and ethical judgement," Procedia Social and Behavioral Sciences, vol. 69, pp. 1676-1683, 2012.

[12] L. Kohlberg, The Psychology of Moral Development: The Nature and Validity of Moral Stages, San Francisco: Harper \& Row, 1984.

[13] J. Haidt, "The emotional dog and its rational tail: A social intuitionist approach to moral judgment," Psychological Review, vol. 108, no. 4, pp. 814-834, 2001.

[14] L. Kohlberg, Stage and Sequence. The Cognitive Developmental Approach to Socialization, Chicago: Rand McNally, 1969.

[15] H. A. Simon, "What is an 'explanation' of behaviour?" Psychological Science, vol. 3, pp. 150-161, 1992.

[16] R. Haines and L. N. K. Leonard, "Individual characteristics and ethical decision-making in an IT context," Industrial Management \& Data Systems, vol. 107, no. 1, pp. 5-20, 2007.

[17] P. N. Rajeev, "Exploring moral action: A critical review of integrative models and suggestions for future research," Journal of International Business Ethics, vol. 4, no. 2, pp. 53-65, 2011.

[18] P. Alleyne, C. Cadogan-McClean, and A. Harper, "Examining personal values and ethical behaviour perceptions between accounting and non-accounting students in the Caribbean," The Accounting Educator's Journal, vol. XXIII, pp. 47-70, 2013.

[19] P. Alleyne, D. Devonish, J. Allman, W. Charles-Soverall, and A. Y. Marshall, "Measuring ethical perceptions and intentions among undergraduate students in barbados," The Journal of American Academy of Business, Cambridge, vol. 15, no. 2, pp. 319-326, 2010.

[20] D. A. Becker and I. Ulstad, "Gender differences in student ethics: Are females really more ethical?" Plagiary: Cross-Disciplinary Studies in Plagiarism, Fabrication, Falsification, and Falsification, vol. 2, pp. 77-91, 2007.

[21] J. R. Cohen, L. W. Pant, and D. J. Sharp, "An examination of differences in ethical decision-making between Canadian business students and accounting professionals," Journal of Business Ethics, vol. 30, no. 4, pp. 319-336, 2001.

[22] D. Devonish, P. Alleyne, C. Cadogan-McClean, and D. Greenidge, "An empirical study of future professionals' intentions to engage in unethical business practices," Journal of Academic Ethics, vol. 7, no. 3, pp. 159-173, 2009.

[23] M. Ludlum, S. Moskalionov, and V. Ramachandran, "Examining ethical behaviors by business students," American International Journal of Contemporary Research, vol. 3, no. 3, pp. 13-21, 2013.

[24] M. McCuddy and B. Peery, "Selected individual differences and collegians' ethical beliefs," Journal of Business Ethics, vol. 15, no. 3, pp. 261-272, 1996.

[25] S. Sankaran and T. Bui, "Relationship between student characteristics and ethics: Implications for educators," Journal of Instructional Psychology, vol. 30, no. 3, pp. 240-253, 2003.

[26] A. C. McCabe, R. Ingram, and M. C. Dato-on, "The business of ethics and gender," Journal of Business Ethics, vol. 64, no. 2, pp. 101-116, 2006.

[27] P. O'Clock and M. Okleshen, "A comparison of ethical perceptions of business and engineering majors," Journal of Business Ethics, vol. 12, no. 9, pp. 677-687, 1993.

[28] D. E. Allmon, H. C. K. Chen, T. K. Pritchett, and P. Forrest, "A multicultural examination of business ethics perceptions," Journal of Business Ethics, vol. 16, no. 2, pp. 183-188, 1997.

[29] D. E. Allmon, D. Page, and R. Roberts, "Determinants of perceptions of cheating: Ethical orientation, personality and demographics," Journal of Business Ethics, vol. 23, no. 4, pp. 411-422, 2000.

[30] T. N. Barone, "Moral dimensions of teacher student interactions in Malaysian secondary schools," Journal of Moral Education, vol. 33, no. 2, pp. 179-196, 2004.

[31] S. McAllister. (2009). Critical Thinking Development Report: A Review of Current Best Practice, Research in the Field and Selected Programs. [Online]. Available: http://www.criticalthinkingblog.org/wp-content/uploads/2010/10/Crit ical-Thinking-Development-Report-McAllister-2009.pdf

[32] M. M. Saat and R. A. R. Ahmad, "Ethical exposure in practical training," Accountants Today, pp. 14-21, 2009.

[33] C. O'Leary and S. Mohamad, "A tri-national study of accountancy students' ethical attitudes," Malaysian Accountancy Review, pp. 139-157, 2006.

[34] S. Waddock, Encyclopedia of Business Ethics and Society, Thousand Oaks, CA: SAGE Reference Online, 2007.

[35] R. Wilkinson and I. Yussof, "Public and private provision of higher education in Malaysia: A comparative analysis," Higher Education, vol. 50, no. 3, pp. 361-386, 2005.

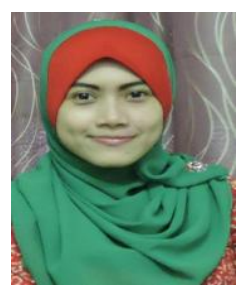

Shazaitul Azreen Rodzalan obtained her bachelor degree in management of technology from Universiti Teknologi Malaysia in 2011. She currently is pursueing her doctorate study in management at Faculty of Management, Universiti Teknologi Malaysia. Her research interests include generic skills development, industrial training and higher learning education.

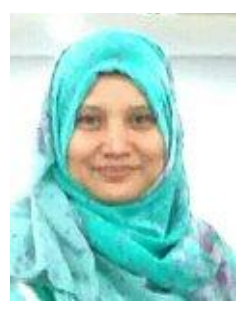

Maisarah Mohamed Saat is a senior lecturer at the Faculty of Management Universiti Teknologi Malaysia, with 16 years of teaching experience. She obtained her bachelor of accountancy from Universiti Utara Malaysia, the master of accountancy from Universiti Kebangsaan Malaysia and the $\mathrm{PhD}$ in accounting from Australia. Her research interests include accounting behaviour, auditing, business ethics and ethics education. 